\title{
An integrated model of organisational innovation and firm performance: generation, persistence and complementarity
}

Our paper encompasses an integral view of organizational innovation (OI), covering from the generation of OI to the effect of OI on firm performance, tackling the gap identified by Damanpour et al. (2009) about the lack of studies that comprehensively study OI. We empirically test this question using data from the Spanish Technological Innovation Panel (PITEC, 2016) carried out in the years 2008-2013, focusing on a sample of 3,795 manufacturing firms. The results provide empirical evidence that confirms OI as an innovation capability. We conclude that innovation capabilities operate through a reciprocity and complementarity relation, where technological, product and process, innovations and OI are all determining factors of one another. Last, our paper explores the effect of OI on firm performance, expanding the current analysis of the effect of process and product innovation on firm performance.

\section{Introduction}

Firms adopt organisational innovation (OI) to achieve business objectives in terms of operation efficiency, quality control, learning, product and process innovation, or market development (Damanpour et al., 2009; Damanpour and Schneider, 2006; Robbins and O'Gorman, 2015). As such, OI serves as an important strategic means to improve firm performance (Armbruster et al., 2008; Camison and Villar-Lopez, 2014; Karlsson and Tavassoli, 2016), create value (Hwang et al., 2008; Hamel, 2009), develop technology (Camison and Villar-Lopez, 2014; Ballot et al., 2015), and achieve and sustain competitive advantage (Hamel, 2009; Crossan and Apaydin, 2010). OI is the creation or adoption of an idea or behaviour new to the organization (Daft, 1978; Damanpour and Evan, 1984; Damanpour, 1996; Martin-Rios and Pasamar, 2018). As shown by recent evidence, a good portion of firms engage in OI (e.g. Karlsson and Tavassoli, 2016; Schmidt and Rammer, 2007).

In spite of the significance of OI, and the empirical contributions in the last decade (Hamel, 2009; Damanpour et al., 2009; Damanpour and Aravind, 2012; Evangelista and Vezzani, 2011; Doran, 2012; Camisón and Villar-Lopez, 2014; Ballot et al., 2015), there is still relatively little literature on OI (Fagerberg and Sapprasert, 2010). Contrary to the fact that innovations in organizations include generation and adoption of technological and non-technological innovations, the technology-centric view of innovation continues to dominate (Černe, Kaše and Škerlavaj, 2016; Crossan and Apaydin, 2010; Damanpour, 2014; Volberda, Van Den Bosch and Heij, 2013). Moreover, the limited extant research on OI is fragmented. Research from 
different perspectives has developed different approaches to understanding the phenomenon of OI and have conceptualised it in different ways. Some studies have conceived OI as an antecedent and have tried to determine its effects on product and process innovation, and on firm performance (FP) (Camison and Villa-Lopez, 2014). Others have considered OI as a process and have focused on understanding how it is originated, developed and embedded in the routines and activities of organizations (Mol and Birkinshaw, 2009; Damanpour and Aravind, 2012).

Nonetheless, as pointed out by Hamel (2006) and Armbruster et al. (2008), the generation of OI and its effects on firm performance are still poorly understood. Whereas the OI literature has identified either environmental or organisational factors as determinants of OI (Brandyberry, 2003; Damanpour, 1991; Schmidt and Rammer, 2007), the dual role of internal and external factors on the generation of OI is underresearched. Recently, Damanpour, Sanchez-Henriquez and Chiu's (2018) research proposes and confirms the effect of internal and external sources of knowledge and information on the adoption of managerial innovation in service organisations. Since managerial innovation is only one type of OI, we still do not know whether the source duality applies to the broader context of OI. Damanpour et al. (2018) have thus called for more research on the dynamic effect of internal and external sources on both generation and adoption of innovations, including OIs. Moreover, recent research shows that those firms pursuing more than one type of innovation are better off than those which pursue only one type of innovation at a time (LeBas and Poussing, 2014; Tavassoli and Karlsson, 2016). The combinative effects of innovation types suggest the existence of various interrelationships and complementarities between innovation types. Extant research finds that organizational innovations are beneficial for other types of innovation, especially process innovation (Germain, 1999; Hollen, Van Den Bosch, Volberda, 2013), and for product innovation (Staropoli, 1998). However, empirical evidence is inconclusive concerning whether complementarities are sequential or simultaneous. The interactions between technological innovation (i.e., product and process innovation) and organisational innovation have further complicated the study of OI generation and its impact on firm performance ((Evangelista and Vezzani, 2010; Doran, 2012; Ballot et al., 2015). In general, although most research highlights the complementary nature of technological innovation and OI in their effect on firm performance, these results are inconclusive. Damanpour and Aravind (2012) conclude there is a lack of literature that comprehensively studies OI from its generation process to its impact on firm performance. 
This paper aims to join the different aspects of OI analysed by previous studies to provide a unified framework in which questions concerning the factors generating OI, the interactions between OI and technological innovation and the impact of OI on FP can be studied. We use the resource-based perspective and dynamic capabilities as our theoretical frameworks. These dual theoretical lenses allow us to conceptualize OI as an innovation capability, similar to technology innovation capability (Cohen and Levinthal, 1990), and to investigate the role of OI in the firm resources-performance nexus. In this integral model of OI, we argue that OI mediates between resources and FP. In other words, resources work through OI in terms of organizational processes and routines to help firms achieve superior performance. Using this integrated model, we advance a more nuanced understanding of the generation of OI, complementarities of OI with technological innovation, and combinative effects of OI and technological innovation on firm performance. First, we build on Damanpour et al. (2018) to investigate the dual role of internal and external resources in the generation of OI. We argue that internal and external resources affect the generation of OI in firms. Second, Building on Cohen and Levintal (1990) and Tavassoli and Karlsson (2015), who have pointed out that one feature of innovation capabilities is the cumulative learning nature, we argue that knowledge obtained from past OI supports new OI, suggesting the effect of persistence on the generation of OI. We thus investigate how previous OI impact in firms' current engagement in OI. Third, we verify the nature and effects of complementarity. Damanpour et al. (2009), and Camison and Villar-Lopez (2014) point out that innovation capabilities interact between them, as a consequence of the affinity of routines and processes, synergistic effects of learning, and reduction of time needed in this interaction (complementarity). For this, we firstly analyse the interactions between technological innovation and OI. We particularly focus on analysing the impact of technological innovations on OI generation in order to clarify whether complementarity is sequential or simultaneous. This addresses the concern raised by Damapour et al. (2009) about the necessity of understanding the interactions between organisational and technological innovations. We then build on Damanpour et al. (2009), Doran (2012), Camison and VillarLopez (2014), and Ballot et al. (2015), and investigate the combinative effects of technological and organisational innovation on firm performance.

We empirically test our integrated model of OI using data from the Spanish Technological Innovation Panel (PITEC, 2016) carried out in the years 2008-2013, focusing on a sample of 3,795 manufacturing firms included in all the waves of this panel. There are several reasons for the choice of PITEC. First of all, it allows to compare and to generalise the results as PITEC uses the harmonised CIS questionnaire, which is commonly used in literature (e.g. Ballot et al., 
2015; Evangelista and Vezzani, 2010). Secondly, PITEC allows for a panel set up, which enriches and extends previous studies by providing a longitudinal approach (Camisón and Villar-López, 2014). Thirdly, it allows us to approach the study of interactions and complementarities. Hullova (2016) points out that is necessary to study the whole industry and not individual sectors, considering that companies can work with a large portfolio of projects involving several sectors (Bruch and Bellgran, 2014).

\section{Conceptual Framework}

\subsection{The resource-based perspective and dynamic capabilities perspective}

The theoretical frameworks used in this paper are the resource-based perspective (RBP) and dynamic capabilities of the firm (Wernerfelt, 1984; Barney, 1991; Peteraf, 1993; Eisenhardt and Martin, 2000; Nelson and Winter, 2002; Zahra et al., 2006; Teece, 2007). RBP postulates that the development of valuable resources in a proactive environmental strategy is the source of firms' competitive advantage (Sharma and Vredenburg, 1998). So, RBP scholars (e.g. Barney, 1991; Peteraf, 1993) conceptualise firms as bundles of resources that link to firms' superior performance. Furthermore, dynamic capabilities theory argues that a firm's superior performance depends on its capacity to deploy these resources using organisational processes (Barney et al., 2001). Such capacity is conceptualized as capabilities (Cohen and Levinthal, 1990) or more specifically dynamic capabilities that are defined as "the firm's ability to integrate, build, and reconfigure internal and external competencies to address rapidly changing environments" (Teece et al., 1997, p. 516). Thus, the tenets of the combined perspectives are that resources are transformed and accumulated inside the firm and embodied in individuals and groups, structures, technical and management systems, and in regulations, values, procedures and behaviour patterns (Leonard-Barton, 1992) and that capabilities are presented as specific and identifiable processes, through which the firm manages its resources to achieve good performance (Eisenhardt and Martin, 2000; Cohen and Levintal, 1990).

\subsection{OI innovation as innovation capability}

Firms response to rapidly changing environments can be best achieved through innovation. Yet, Schumpeter and other innovation researchers (e.g., Damanpour and Evan, 1984; Totterdell et al., 2002; Martin-Rios and Parga, 2016a; Heredia et al., 2019) have identified innovation as a complex phenomenon, including technical (e.g., new products, new production methods) and non-technical aspects (e.g., new markets, new forms of organization). Technical innovations are related to product and process innovations, and non-technical innovations are associated with marketing and organizational innovations (Mothe and Nguyen, 2010, 2012; Martin-Rios 
and Parga, 2016a, 2016b; Pino et al., 2016; Oeij et al, 2019). In this context, there have been multiple approaches to non-technical innovations. More specifically, the phenomenon of 'organizational innovation' is subject to different interpretations within the different strands of literature (Lam, 2005). For example, it can be found in organizational design theories that observe the link between structural forms of an organization and product and process innovation; it can also be found in research on organizational change and adaptation that concerns the processes underlying the creation of new organizational forms. This has meant that the conceptualization of OI has been considered as a process, as an output of the firm, or as a prerequisite, among others (Geldes et al., 2017; Martin-Rios and Pasamar, 2018). However, despite this dispersion of approaches and focuses, there is certain consensus in the literature that refers to organizational innovations as comprising changes in the structure and processes of an organization due to implementing new managerial and working concepts and practices, such as the implementation of teamwork in production, supply chain management or quality management systems (OECD, 2005; Damanpour, 1987; Damanpour and Evan, 1984). Consistent with this line of thinking, this paper defines OI as the introduction of all the changes that aim to improve existing processes at the core of an organisation's structure (EUROSTAT, 2005; OECD, 2005). From this point of view, OI in a firm, either as innovations in work processes, workplace practices, or new organizational methods in external relations, is considered a source of competitive advantage, thereby having an impact on firm performance in terms of productivity, delivery times, quality and flexibility (Armbruster et al., 2008). This definition that considers OI as an innovative change differs from the one used in Damanpour (1991) and Sorensen and Stuart (2000), but it is consistent with Schumpeter's concept of "new ways of organising business". Moreover, if organisations are capable of successfully implementing certain organisational changes, it is because they have the ability to integrate and combine their resources to obtain a sustainable innovative performance (Cohen and Levinthal, 1990; Lawson and Samson, 2001).

This conceptualization of OI is similar to that of innovation capability. Cohen and Levinthal (1990) introduced the concept of innovation capability, outlining it as a series of processes and organisational routines that allow the company to seek out, acquire, assimilate and use resources. These innovation capabilities manifest themselves in firms' innovation processes; that is, the capabilities of organisations to successfully adopt and implement new ideas, processes and products (Hurley and Hult, 1998).

Conceptualization of OI as an innovation capability highlights four properties of OI, namely mediation, duality of sources, persistence, and complementarity. First, consistent with Cohen 
and Levinthal (1990), OI as an innovation capability plays a mediating role between resources and firm performance. In other words, the firm's capability in terms of OI is developed by converting resources into innovative products, processes and organisational changes, thereby explaining how companies achieve greater levels of firm performance. Second, related to the theory of absorptive capacity (Cohen and Levinthal, 1990), the generation of OI is more likely if it is enabled by internal and external resources, indicating the property of duality of sources. Third, in line with Pavitt (1984), Sapprasert and Clausen (2012), and Triguero and Córcoles (2013), such innovation capabilities are characterized by persistence over time. Persistence means that an innovation process is the process of "creative accumulation", whereby knowledge obtained from past innovation supports new innovations. In this sense, Pavitt (1984) and Gallouj (2002) suggest that firms innovate on the basis of competences and skills acquired from their past history of innovation. This process of 'creative accumulation' produces internalisation and penetration of innovation, generating skills and capabilities for better exploitation of resources (Ahuja and Katila, 2001; Souitaris, 2002). Fourth, different types of innovation capabilities of the firm are interrelated, as a consequence of the affinity of capacities, processes and routines (Damanpour and Evan, 1984; Camisón and Villar-López, 2014). Doran (2012), Camisón and Villar-López (2014) highlight, in addition, the complementarity potential of this interrelation, as a consequence of learning and the reduction of time that occurs. It can, therefore, be argued that OI as an innovation capability mediates the relationship between resources and performance in the sense that it is generated by resources and that it, in turn, has a positive impact on firm performance. Moreover, it can be argued that past OI developments have an impact on subsequent OI developments, suggesting persistence over time. It can also be argued that $\mathrm{OI}$ is interrelated with other innovation capabilities, thus producing complementarities in the relationship.

\section{Hypotheses}

\subsection{Duality property: Internal and external resources as drivers of OI}

RBP indicates that resources should affect firms' capabilities through the development of competencies, the control of firms' activities, and the creation of new organisational routines (Peteraf, 1993; Grant, 1996; Eisenhardt and Martin, 2000; Anzola-Román et al., 2018). These resources can range from information to equipment or workforce (Galende and de la Fuente, 2003; Urgal et al., 2011). RBP literature contains numerous empirical studies that show how internal and external resources are generators of capabilities in the form of technical innovations (Polder et al., 2010; Urgal et al., 2011; Anzola-Román et al., 2018). Schmidt and Rammer 
(2007) suggest that resources generating technical innovation are similarly the sources of capabilities as manifested in non-technical innovations.

With regard to internal resources, as indicated by Miller et al. (2007), the main input for innovation processes is knowledge resources. First, previous studies have highlighted the role of staff training as a generator of firms' knowledge resources (Lado and Wilson, 1994; Frambach and Schillewaert, 2002). Training programmes have an impact on competences, skills and firms' capabilities, which may then be translated into the introduction of organisational changes such as innovations in job positions and/or organisational processes (Tsai, 2004; Jiménez and Sanz-Valle, 2011). Therefore, we can argue that training programs in the company will generate knowledge, which will have a positive effect on the development of OI. Second, the existence of an $R \& D$ department has also been highlighted as a knowledge source, being a key driver in the development of the firm's technical innovation capabilities (Grenan, 2003; Galende and Fuente, 2003). Galende and Fuente's research (2003) finds a positive impact of the knowledge and skills of R\&D departments' staff, and the department's degree of professionalisation and formalisation on the development of innovation capabilities. Having in-house R\&D staff, where the firm's innovation capability is based on the intelligence, imagination and creativity of its employees (Gupta and Singhal, 1993; Mumford, 2000), is expected to have a positive influence in the introduction of improvements and organisational changes. For example, Camisón and Villar-López (2014) point out that the development of a new product by the R\&D department supposes that it raises the need to develop new process and organizational innovations in the company. Hence, we propose:

H1. OI is generated by the internal resources of the company.

H1a. Staff training has a positive effect on OI.

$H 1 b$. Internal R\&D has a positive effect on $O I$.

In terms of external resources, the first resource is related to cooperation agreements. Gilsing et al. (2008) point out that one of the main ways of accessing the experience and knowledge resources developed by other firms in their innovation activities is by establishing cooperation agreements with them. These cooperation agreements allow the firm to interact with partners. The sharing of knowledge, streamlining and co-developing of procedures, routines and systems in the organisations involved entail organisational changes and organisational innovations in the firm (Grant and Baden-Fuller, 2004; Arranz and Fernandez de Arroyabe, 2016). Secondly, the acquisition of external technological resources such as equipment or technological knowledge acquired in external learning (PITEC, 2016) is also an element that generates innovation capabilities (Mangematin and Nesta, 1999; Fey and 
Birkinshaw, 2005). Thus, it can be expected to impact OI as a consequence of the necessity to create new organisational changes in both firms' processes and work positions that will permit the incorporation of this new equipment or new knowledge into the firm. Additionally, knowledge resources acquired by the company can be expected to have a positive influence on innovation changes at the organisation. Thirdly, information acquired externally may serve as a resource for developing firms' innovation since the combination of new ideas with firms' existing knowledge may lead to the development and deployment of new routines and practices (McEvily and Chakravarthy, 2002; Chesbrough, 2005). This external information may come from the market, different institutions, trade fairs, seminars, and journals, among others (PITEC, 2016). The external information sources can, therefore, be assumed to have a positive incidence on OI. Finally, external finance is an important resource used to incentivise innovation in enterprises (Da Silva et al., 2017; Choi et al., 2016). Innovative development requires firms to have adequate financial resources to develop this process. In this context, various institutions develop financing facilities for innovations, encouraging the incorporation of organizational changes in the firm (Damanpour, 2010). Therefore, we can argue that similar to the effects of internal resources on OI, there is a positive relationship between external resources and OI. Hence, we propose:

H2. OI is generated by resources external to the company.

H2a. Cooperation agreements have a positive effect on OI.

H2b. External technological resources have a positive effect on OI.

H2c. Informational resources have a positive effect on OI.

H2d. External financing has a positive effect on OI.

\subsection{Mediating property: the effect of OI on FP}

Regarding the effect of OI on FP, the literature highlights the close relationship between OI and productivity and suggests that its adoption leads to a more efficient management of human resources, positive changes in the incentive structure of workers or optimisation of the resources used in production (Armbruster et al., 2008; Damanpour and Aravind, 2012; Camisón and Villar-López, 2010; Sapprasert and Clausen, 2012). Such a relationship has been confirmed in empirical research. For example, Black and Lynch (2004) have reported that about $30 \%$ of productivity gains in the US manufacturing sector in the 1990s can be traced back to factors related to the adoption of OI practices. Damanpour and Schneider (2006) find that firms undertaking OI activities showed improved firm performance, for example, in the reduction of administrative costs or supply expenditures, or an increase in workers' satisfaction, which in turn increased workers' productivity. Damanpour et al. (2009) also find that organizational 
performance from adopting compositions of innovations had a positive effect over time among public service organizations. Hence, we propose:

H3. There is a positive effect of OI activities on FP.

\subsection{Persistence property as drivers of $\mathrm{OI}$}

To fully understand the OI drivers, it is also necessary to analyse the OI history of the firm. Changes within organisations have been shown to be a cumulative and self-reinforcing process (Amburgey and Miner, 1992), which produces a competence-enhancing effect. As a result, persistent organisational innovators have a higher ability to effectively and successfully reorganise repeatedly (Triguero and Córcoles, 2013), and may benefit more from doing so (Malerba and Orsenigo, 1999). Nelson and Winter (1982), Aldrich (1999), and Kelly and Amburgey (1991) highlight that firms may be more able to routinize changes by developing a "modification routine". This analysis is consistent with studies on the persistence of technological innovations (Flaig and Stadler, 1994; Crepon and Duguet, 1997; Peters, 2009; Sapprasert and Clausen, 2012; Tavassoli and Karlsson, 2015), which consider the innovation process as a process of "creative accumulation" (Rosenberg, 1976). Thus, knowledge obtained from past innovation supports new innovations, as a consequence of learning and generation of economies of scale during the development process (Sapprasert and Clausen, 2012; Tavassoli and Karlsson, 2015). Consistent with this line of argument, we can extend previous literature by considering the effect of persistence of OI in that previous OI is conducive to the development of future OI. Hence, we propose:

H4. Past organizational innovation increases the probability of future organizational innovation.

\subsection{Interrelation property: Interrelation between technological innovations and OI}

As emphasised by the dynamic capabilities approach, the generation of firms' capabilities entails the development of tasks, routines and teams for the achievement of firm performance (Leonard-Barton, 1992; Grant, 1996; Eisenhardt and Martin, 2000; Barney et al., 2001). Doran (2012) points out that the interaction between capabilities arises as a consequence of the need to develop tasks and previous routines or the affinity between them that makes them share. In this sense, Hullova et al. (2016) study the order of interaction among technological innovations and classify them according to whether the interaction is simultaneous or sequential. Their study suggests that interactions between process and product innovations may be sequential. Additionally, Milgrom and Roberts $(1990,1995)$ and Schmiedeberg (2008) emphasize the 
degree of interaction, indicating whether it has a complementary character or not. Therefore, in our paper, we analyze both the order of the interaction and the existence of complementarity.

Regarding the interaction order between technological innovation and OI, both sequential and reciprocal interactions can be found in the literature. For example, Hervas-Olivier et al. (2012) report a sequential relation between OI and process innovation, where the development of organisational innovation increases the likelihood of introducing process innovation. Moreover, Damanpour and Gopalakrishnan (2001) point out that OI is a pre-condition for the development of new products, derived from the necessity of introducing changes in job positions and organisational process that facilitate the new product development processes. In fact, these authors show that OI is the framework for the development of technological innovations. However, Mohnen and Röller (2005), and Polder et al. (2010) recognize that product development implies organizational changes, both in the firms' structure and marketing processes, both sequentially before the need to introduce the new product in the market, and simultaneously, with the creation of work teams to develop the new product. Camison et al. (2010) emphasize in the sequentiality of interaction, arguing that innovation process generates organizational innovation through the adaptation of job positions to the new process. For example, the introduction of flexible production system has as consequence to change in the way tasks and jobs shifts are assigned. Damanpour (2010) emphasizes reciprocity, pointing out the difficulties of distinguishing process and organisational innovation. This is the case of the introduction of a quality system in the control of production, where changes in processes are accompanied by organizational changes. Robbins and O'Gorman (2015) show that both types of innovation can be used by managers to reduced production costs through newer and more efficient production, distribution and internal organisation processes. Taken all together, the literature leans towards a reciprocal or simultaneous relation between both technological innovation and OI. Hence, we propose:

H5. OI is interrelated with technological innovation.

H5a. OI and technological innovation have a sequential relationship.

H5b. OI and technological innovation have a simultaneous relationship.

Regarding the existence of complementarity between technological innovation and OI, there are several studies that report the potential synergistic or complementary effect between technological innovation and OI (e.g. Doran, 2012; Ballot et al., 2015). This complementary effect derives from the sharing of competencies, resources, and routines in the process of capability development, through economies of scale and learning processes in the development of these capabilities (Damanpour and Evan, 1984; Eisenhardt and Martin, 2000; Camisón and 
Villar-López, 2014). Doran (2012, p. 354) defined complementarity across R\&D activities 'as existing if the engagement of a firm in two types of R\&D activity simultaneously resulted in greater returns to the firm than engagement in either of these forms of $R \& D$ separately' ${ }^{1}$. Moreover, Milgrom and Roberts (1990, 1995) distinguished between two types of complementarity: complementarity-in-use and complementarity-in-performance. Complementarity-in-use refers to the complementarity between technological innovations. Complementarities-in-performance is defined as the complementarity between technological innovations, and their impact on firm performance.

Regarding complementarity-in-use or complementarities between innovations, it assumes that two innovations made together increase the probability of making a third type of innovation, more than if the two innovations were made separately. In this line, Camisón and Villar-López (2014, p. 2893) point out that 'when a firm has introduced OI, to accumulate capabilities to introduce new products in the market, OI needs an appropriate organizational infrastructure as well as engineering and technological skills to design the production processes, layout, and logistics to efficiently support the new product design and its commercialization'. Prajogo and Sohal (2006) observe that quality control in a company improves technological innovation when developing a product. An adequate organisational innovation, for example, job tasks design, affects the efficiency of new products development process (Damanpour, 2010). Trott (2010) finds that in the beer company Guinness, the development of a new container for the beer brought along changes in the processes as well as in the organisation, both in job positions and in the firms' procedures. In general, literature concludes that both technological innovations and OI have a complementary effect (see for example, Camisón and Villar-López, 2014). Therefore, we see that the development of OI along with technological innovation facilitates the further development of innovation capabilities in the firm, as a consequence of accumulating capacities and synergies in the process of developing them. Hence, we propose:

H6. OI and technological innovations have a complementary relationship.

To fully understand the effect of OI on FP, it is also necessary to analyse the effect on the performance of OI in interaction with technological innovation (Grunday et al., 2011; Geldes et al., 2017; Lee et al., 2017). Although the literature highlights the complementary effect of

\footnotetext{
${ }^{1}$ For example, Milgrom and Roberts (1990) point out that doing more than one innovation activity increases the returns to doing more of another. In the simplest case in which two innovations $\mathrm{x}$ and $\mathrm{y}$ take two values, 0 and 1 , the complementarities are expressed by the following condition on the objective function $f(x, y)$, where $f(1,1)$ corresponds to the presence of both innovations $\mathrm{x}$ and $\mathrm{y}$, and $\mathrm{f}(1,0)$ the presence of $\mathrm{x}$ and absence of $\mathrm{y}$ : $\mathrm{f}(1,1)-\mathrm{f}(1,0)>\mathrm{f}(0,1)-\mathrm{f}(0,0)$

Such a function is said to be strictly super-modular in $\mathrm{x}$ and $\mathrm{y}$, existing complementarity between both innovations (Mohnen and Röller, 2005).
} 
technological innovations and OI on firm performance, empirical findings are nonetheless inconclusive. Camison and Villar-Lopez (2014) report a complementary effect between OI and process innovation on FP, but they find no clear complementarity between OI and product innovation. Doran (2012) uses the Irish CIS (2004-2006) to test complementarity. While his findings reveal the existence of complementarity in some cases, he finds no substitutability between the different types of innovations. Battisti and Stoneman (2010) use data from CIS4 for the UK to study complementarity between innovation types and classify the degree of complementarity in different sectorial clusters. Ballot et al. (2015) study the case of the French and UK CIS report that complementarities between product, process and OI have a contingent nature, with differences between the UK and France. Following Camison and Villar-Lopez (2014), we argue that the development of OI combined with process innovation will generate greater efficiency in the productive processes, thereby achieving savings in time or costs. Likewise, the development of OI with product innovation will facilitate, for example, the introduction of the product in the market, by combining logistics developments, or marketing channels specifically for the new product. Hence, we propose:

H7. OI and technological innovation have a complementary effect on FP.

\section{Research Methodology}

\subsection{Unit of analysis and target study population}

In this research, the unit of analysis is the firm, and the data are collected from the Spanish Technological Innovation Panel (PITEC). This survey is conducted bi-annually by Spain's National Statistics Institute (INE) since 2001 and replicates the standardised questionnaire used by the Community Innovation Survey (CIS), following the guidelines of the Oslo Manual (OECD, 2005). PITEC contains firm-level data, including information about the company (employment, sales, geographic market, industry sector, etc.) as well as detailed information regarding its innovation activity (innovation expenditures, different kinds of innovation output, cooperation between firms, public financial support, barriers to innovation, and so on).

The reference period for this study is $2008-2013^{2}$. After a filtering process ${ }^{3}$, the final sample is a balanced panel containing 3,795 manufacturing firms (22,770 firm-year observations), from which 2,622 firms have conducted some sort of organisational innovation over the period of study. Table 1 shows the main descriptive features of the firms.

\footnotetext{
2 The data for the period 2008-2013 was extracted from the two PITEC waves of 2008-2010 and 2011-2013.

${ }^{3}$ Our initial sample consisted of 61,119 firm-year observations; we removed those firms for which the data of any of the years 2008-2013 was missing (8,451 observations). We dropped firms with less than 10 employees $(8,166$ obs.), firms that were part of M\&As (2,958 observations), and firms that did not belong to manufacturing sectors $(18,774$ observations).
} 


\subsection{Measures:}

\section{Organizational Innovation}

PITEC categorises organisational innovation in three ways: i) internal functioning of the firm (including methods/systems of knowledge management) (OII); ii) organisation of the workplace (OI2) and; iii) external relations that have not been previously used by the firm $(O I 3)$. Each of these categories is measured by a dummy variable defined as 0 if no activities in that particular category have taken place and 1 if they have. Following Armbruster et al. (2008) and based on these three categories, we generate a dummy variable, organisational innovation (OI), that is coded as 1 if the company has successfully engaged in any of the three types of organisational innovation in the period of study, and 0 otherwise.

\section{Firm Performance}

Following previous empirical studies using the CIS data (see e.g. Ballot et al., 2015; Doran, 2012 ), we proxy firm performance (FP) on period $t$ as the ratio of sales (in Euros) to the number of employees on year $t$. In order to account for the skewness of the distribution of this variable, a log-transformation is used for the variable.

\section{Internal Resources}

As discussed in the preceding section, this study considers internal $R \& D$ and staff training as two important types of internal resources. Internal R\&D is measured by the number of people working at the company's R\&D department on period $t$. Following Brusoni et al. (2005), the variable $R \& D$ staff ( $R \& D$ staff) is constructed as the ratio of the number of people dedicated to internal $\mathrm{R} \& \mathrm{D}$ activities over the total number of employees in period $t$. Staff training is measured by training activities (Training) undertaken within the firm. In the questionnaire, this is a dummy variable with a value of 1 if the company runs any type of training activities aimed at the development or introduction of innovative products or processes in period $t$, and 0 if not.

\section{External Resources}

We use four variables to capture external resources. The first variable is cooperation in innovation (Cooperation). The PITEC questionnaire considers cooperation in innovation as a dummy variable that has a value of 1 if the company cooperated on any technological innovation activities during period $t$. The second variable of external resources is external acquisitions. In this category, PITEC considers external R\&D that has been contracted out to other enterprises like, for example, knowledge or equipment acquisition. The questionnaire includes three dummy variables: i) External acquisition of $R \& D$ contracted out to other enterprises (External $R \& D$ ); ii) Acquisition of machinery, equipment, hardware or software (External equipment); iii) Acquisition of other knowledge for innovation (copyrighted works, 
patented and non-patented inventions) (External knowledge). The third variable of external resource is information sources, which considers the intensity of use and the diversity of the sources consulted). The intensity of the sources is rated on a scale of 1 to 4 : a value of 1 is assigned if the degree of utilisation is high; 2 if it is intermediate; 3 if it is low; and 4 if it is null. The PITEC questionnaire distinguishes between ten different external sources: i) Suppliers; ii) Customers; iii) Competitors; iv) Consultants and commercial laboratories; v) Universities; vi) Public research entities; vii) Technology centres; viii) Conferences, trade fairs and exhibitions; ix) Scientific journals; $x$ ) Professional and industry associations. We aggregate these external sources (Cronbach's alpha: 0.967) into one single indicator (Information source) defined as 10 over the total sum of the intensity of each type of source ${ }^{4}$. The fourth variable is the use of external public funding to develop innovation processes. PITEC distinguishes public funding according to origin: i) from local or regional governments; ii) from the national government; iii) from the European Union. It reflects the use of public funding with a dummy variable (Public Funding) equal to 1 if the company receives any public funding from any of the above-mentioned institutions in period $t$, and 0 otherwise.

\section{Technological innovations}

PITEC questionnaire measures technological innovations with two variables. The first is a dummy variable, product innovation ( $p d i$ ), which is coded as 1 if the company has successfully completed at least one of the following types of product innovation in the reference period: i) in goods and; ii) in services.

The second variable is process innovation. Similarly, process innovation (pci) is a dummy variable. It is coded as 1 if the company has successfully completed at least one of the following types of innovation processes in the reference period: i) in manufacturing methods; ii) in logistical systems or in the delivery and distribution methods for their inputs, goods and services; and iii) in support activities for their processes, such as systems for maintenance and IT operations, procurement and accounting.

\section{Control variables}

We control for the level of technology intensity of different manufacturing industries included in the sample. We follow the OECD (2011) ISIC rev.3 classification and distinguish between low-tech and high-tech industries. We generate a dummy variable $(O E C D)$ that is coded as 1 if the firm belongs to either the OECD group of "high-technology industries" or "medium-high-technology industries", 0 otherwise.

\footnotetext{
${ }^{4}$ With this simple linear transformation, we aim to make more readable the results from our regressions, so that a high value of Information Source indicates a high use of external sources of information.
} 
Previous empirical studies have found firms' size to be a determining factor in the adoption of new technological innovations. As standard in management literature, we measure firm size with the log of the number of employees (Size).

A third common variable in studies on innovation is whether the firm belongs to a group. In this case, the questionnaire includes a dummy variable (Group); 0 if it does not belong to a group and 1 if it does.

The final control variable is the international scope of the firm. PITEC questionnaire distinguishes four different geographical markets: i) local; ii) national; iii) EU; or iv) other countries. We include the dummy variable International to control whether the firm operates abroad or not.

\subsection{Econometric model ${ }^{5}$}

For testing our hypotheses, we use a panel ordinal logit regression for hypotheses 1, 2, 4, 5 and 6 , and a linear regression model for hypotheses 3 and 7 . All of the models implemented include random effects that allow us to account for time-invariant characteristics of the firm such as the belonging to a group, or the operation in an international market.

Table 2 explores the effect of internal and external resources on OI (Hypotheses 1 and 2). Based on the measures of OI, we use four different specifications to analyse the effect of firms' resources on OI (Table 2). The dependent variables in Specifications (1) to (3) are three different types of organisational innovation $(O I 1, O I 2, O I 3)$. The last specification uses the encompassing dummy variable $O I$ as the dependent variable. The explanatory variables for these specifications include internal resources ( $R \& D$ staff, Training), external resources (Cooperation; External R\&D; External equipment; External knowledge; Information source; Public funding), and control variables (OECD; Size; Group; International).

In Table 3, we test the effect of OI on FP (Hypothesis 3). We employ a methodology similar to that of Mohnen and Roller (2005), Sharapova and Kattuman (2010), Doran (2012), and Ballot et al. (2015), allowing the analysis of various combinations of innovation output to act as complements or substitutes. In column 1 of Table 3, the dependent variable is Log FP, and the independent variables $(A(i, j))$ are the combinations of $\mathrm{OI}$ in period $\mathrm{t}$ and $\mathrm{OI}$ in the previous period (t-1). For example, A(no OI, L_OI) indicates that the firm does not conduct innovation in period $\mathrm{t}$, but it does in period $\mathrm{t}-1$. Additionally, the regression models include four control variables (OECD; Size; Group; International).

\footnotetext{
${ }^{5}$ For the technological (process and product) and non-technological innovations (OI), the prefix "L_" indicates the lag of the variable (i.e. the variable taken in year t-1).
} 
Table 4 shows the analysis of the existence of persistence in OI (Hypothesis 4). The regression models use OI in period $\mathrm{t}$ as the dependent variable, and OI in the previous period (L_OI; L: last period) as the main independent. This table also includes the lag of product and process innovation and the set of control variables as regressors.

Hypotheses 5 and 6 correspond to the study of the interrelation and complementarity (complementarity-in-use) between technological innovations and OI. To test these hypotheses, we employ a similar methodology applied to the testing of Hypothesis 3. The types of innovation considered are product innovation, process innovation and organisational innovation. As before, the analysis is based on an Ordinal Logit Regression Model with random effects, and the results are presented in two tables. Table 4 uses organisational innovation (columns 1 and 2) as the dependent variable, and the combination of product and process innovation in the same period $(\mathrm{W}(\mathrm{i}, \mathrm{j}))$ as independent variables. For example, W(pdi, no pci) indicates that the firm conducts product innovation but not process innovation in period $t$. Moreover, it tests the persistence of innovation by analysing the impact of past realisations including the lags of the three types of innovation as independent variables. In Table 5, we perform the same analysis, considering product and process innovation as dependent variables. We introduce the combinations of $\mathrm{OI}$ and process innovation $(\mathrm{Y}(\mathrm{i}, \mathrm{j})$ ) and $\mathrm{OI}$ with product innovation $(\mathrm{X}(\mathrm{i}, \mathrm{j}))$ as independent variables. In addition, as in the previous models, we include all three respective innovations in the previous period and four control variables (OECD; Size; Group; International).

Regarding Hypothesis 7, the effect of technological innovation and OI on firm performance (FP), Table 3 shows the regression models (column 2, 3, 4, and 5). First, we analyse the effect of combinations of OI and process innovation (Y (i, j)) and OI with product innovation (X (i, j)) in the same period (column 2 and 3). Second, in column 4 and 5, we analyse the combinations of OI with product innovation in the previous period $(B(i, j))$ and OI with process innovation in the previous period $(A(i, j))$. In addition, as in the previous cases, we include the four control variables (OECD; Size; Group; International).

\section{Results}

Table 1 presents the descriptive statistics of the variables used in the analysis of organisational innovation. Similar to the case of technological innovations (Fagerberg and Verspagen, 2009; Battisti and Stoneman, 2010), firm size is a factor influencing firms undertaking organisational innovation activities. The results also show that over half of the companies that implement this type of innovation receive some type of external funding. 
Similarly, at least half of the companies that carry out organisational innovations run training activities, set up cooperation agreements, use external information sources, and acquire knowledge, machinery and R\&D from outside the company. Also, nearly half of the companies that undertake internal $R \& D$ activities implement organisational innovation activities. The profile of firms in our sample as displayed in Table 1 seems consistent with Gilsing et al. (2008) in that firms that are most open to the outside and have the greatest internal dynamism are more likely to carry out innovation activities.

In terms of organisational innovation and technological innovation activities, it can be seen that a high percentage of firms implement both types of innovation, in line with other studies that report a correlation between both types of innovation (Camisón and Villar-López, 2014). This is particularly evident in the case of process innovation. Damanpour (2010) argues in this regard that it is difficult to distinguish between process and organisational innovation. In fact, many innovations contain both types, as indicated in OECD (2005).

Results in Tables 2 and 3 verify the first two properties of OI, i.e. duality of sources and OI as a mediator in the relationship between resources and FP (Hypotheses 1 and 2). Hypothesis 1 proposes that OI is generated by resources internal to the company. Results in Table 2 show that internal resources, as measured by $R \& D$ staff and training activities, have a positive and significant relationship with OI as a whole (column $4,(\beta=0.61, p<0.001 ; \beta=0.66, p<0.001)$, and with each subcategories of OI (columns 1, 2 and 3), corroborating Hypothesis 1 (Hypotheses 1a and 1b). Hypothesis 2 proposes that OI is generated by resources external to the company. Results of Table 2 show that cooperation $(\beta=0.57, p<0.001)$, external $R \& D(\beta=$ 0.40, $\mathrm{p}<0.001)$, external equipment $(\beta=0.47, \mathrm{p}<0.001)$ and information sources $(\beta=4.89, \mathrm{p}$ $<0.001$ ) have a positive and significant relationship with OI as a whole (column 4) and with all OI subcategories (columns 1-3). Thus, cooperation agreements are observed to be determining factors in developing organisational innovations (Hypothesis 2a), in line with the works of Gilsing et al. (2008), and Arranz and Fernandez de Arroyabe (2008). Similarly, consultation of external information sources such as trade fairs, conferences and market sources, competitors, and consultants, or institutional sources such as universities and research centres is a significant determinant in the development of organisational activities (Hypothesis 2c), corroborating the findings of Pino et al. (2016) and Geldes et al. (2017). The results, however, do not show any evidence of the positive effect of external knowledge acquisition on OI. This inconsistency may be explained by the narrow definition of external knowledge used in the PITEC questionnaire that asks about the external acquisition of patent licenses (either purchase or use) or technical knowledge such as copyrighted works, which leaves out other OI-related external knowledge 
such as new workplace practices and new organisational methods. Accordingly, the data extracted from the questionnaire do not fully capture external knowledge activities that are more pertinent to OI. As for public funding, the results suggest a positive impact on OI, but this result is not consistent across different specifications (Hypothesis 2d). Such inconsistency is also found in previous research such as Martin-Rios and Pasamar (2018) and Heredia et al. (2019). In general, Hypothesis 2 is partially supported.

In Hypothesis 3, we propose that there is a positive effect of OI activities on FP. The first column of Table 3 shows that OI has a positive and significant relationship with FP. This positive relationship is present both when $\mathrm{OI}$ is only conducted in one of the periods $(\beta=0.05$, $\mathrm{p}<0.001)$ and in both periods $(\beta=0.07, \mathrm{p}<0.001)$, corroborating Hypothesis 3 . This last result supports the work of Nelson and Winter (1982), Aldrich (1999), Kelly and Amburgey (1991), Anzola-Román et al. (2018), and Martin-Rios and Parga (2016), which highlight that companies may be more able to routinize change due to the development of "modification routines". In general, the results provide empirical evidence to confirm the effect of OI on FP that is in line with the work of Damanpour (2010), Gunday et al. (2011), Karlsson and Tavassoli (2016), and Martin-Rios and Parga (2016). Therefore Tables 2 and 3 verify that OI mediates between resources and FP, confirming the property of OI as an innovation capability.

Regarding the third property of OI as an innovations capability in terms of persistence over time, Hypothesis 4 proposes that past OI increases the probability of new OI. Results in Table 4 show that conducting OI innovation in the past has a positive impact on $\mathrm{OI}$ in the current period $(\beta=3.17, \mathrm{p}<0.001)$ (Model 1). The result is consistent after controlling for other factors $(\beta=3.14, p<0.001)$ (Model 2$)$. This suggests a cumulative effect on OI and confirms Hypothesis 4.

Regarding OI's interrelation property, i.e. the interrelationship between OI and technological innovations, Hypothesis 5 proposes that $\mathrm{OI}$ is interrelated with technological innovation, in which the interrelation may be sequential or simultaneous. Also, Hypothesis 6 proposes that OI and technological innovation have a complementary relationship. Results in column 2 of Table 4 shows the positive and significant relationship between $\mathrm{OI}$ and, process innovation $(B=0.74$, $\mathrm{p}<0.001)$, product innovation $(\beta=0.19, \mathrm{p}<0.05)$; and the joint effect of process and product innovations ( $(=1.40, \mathrm{p}<0.001)$. The results also show the higher positive effect on OI when both process and product innovation are conducted, suggesting the interrelation of complementarity. The results, however, do not support the existence of a positive effect of past technological innovations on current OI. In Table 5, the left panel shows how OI and product innovation affects process innovation. The results in column 2 show that OI, either undertook 
alone $(\beta=0.58, \mathrm{p}<0.001)$ or in conjunction with product innovation $(\beta=1.17, \mathrm{p}<0.001)$, has a positive and significant impact on process innovation. However, results from the right panel (columns 5 and 6) only find a positive effect of concurrent OI and process innovations on product innovation $(B=0.61, \mathrm{p}<0.001)$. Taken together, the results suggest a complementary effect of the interrelation. Nonetheless, results from Tables 5 do not provide support for the argument that $\mathrm{OI}$ is a pre-requisite of technological innovation, as the coefficients of past OI are either negative or non-significant. Therefore, the results partially corroborate Hypothesis $5 \mathrm{~b}$ but do not support Hypothesis 5a. Taken together, results from Tables 4 and 5 suggest complementarity between OI and technological innovations, corroborating Hypothesis 6 that proposes that OI and technological innovation have a complementary relationship.

Finally, Hypothesis 7 proposes that $\mathrm{OI}$ and technological innovation have a complementary effect on firm performance. The regression models in Table 3 estimate the complementary effect of OI and technological innovation on FP. Regarding the joint effect of OI and technological innovations on FP, results of columns (2) and (3) indicate that there is no synergistic effect. These results, however, change when we take into consideration technological innovations conducted in previous period (columns 4 and 5), where the impact of OI together with prior product innovation $(\beta=0.07, \mathrm{p}<0.001)$ or with prior process innovation $(B=0.07, \mathrm{p}<0.001)$ on $\mathrm{FP}$ is greater than that of product innovation, process innovation, or OI undertook individually. Therefore, the results corroborate Hypothesis 7, suggesting the existence of a synergistic effect between the interrelation of technological innovation and OI on FP.

To check the suitability of our models to explain the different dependent variables, for Tables 3, 4 and 5, we re-estimate the models as a pooled probit and compute the area under the ROC curve (Green and Swets, 1966). For all of our models, the area under the curve ranges between 0.67 and 0.88 , indicating an acceptable predictability power of our models. ${ }^{6}$ For Table 2 , the Rsquared for the different models is around 13\%-17\%, indicating that technological and nontechnological innovations (as well as the control variables) explain about $13 \%-17 \%$ of the variability on firm performance. Additionally, in Table 3, linear regression, we checked the autocorrelation (Durbin-Watson) and collinearity (VIF) of the models, obtaining acceptable values.

\section{Discussion and conclusion}

\footnotetext{
${ }^{6}$ The ROC analysis provides a measure of the accuracy of models to discriminate between different outcomes. A model with perfect predictive power (i.e. all the observations in the sample are correctly classified) will have a value of 1 , while a model with no predictive power will have a value of 0.5 .
} 
This study responds to the recent calls for more OI research on issues such as organisational antecedents, relationships with other types of innovation (Volberda, Van den Bosch and Mihalache, 2014), synchronous patterns of adoption of technological and non-technological innovations, and effects of their joint adoption on performance outcome (Damanpour, 2014). More generally, it aims to tackle the gap identified by Damanpour et al. (2009) in the lack of a comprehensive study of OI in the literature. We take a step in this direction by developing an integrated model of OI to advance a more nuanced understanding of the antecedents, synchronous patterns and effects of OI on firm performance. In doing so, we argue and confirm the dual role of internal and external knowledge in the generation of OI, the cumulative nature of the generation of OI, complementarity between OI and technological innovation, and combinative effects of OI and technological innovation on firm performance. The present study expands the current knowledge of OI in a number of ways.

First, it builds on the resource-based perspective and dynamic capabilities of the firm to conceptualise and confirm the dual nature of OI: as an innovation performance and as an innovation capability. Following the original hypothesis of Cohen and Levinthal (1990), we argue that OI fulfils two requirements of IC: first, it has an effect on the firm's performance, and second, it is fuelled by resources. Moreover, it confirms that OI possesses two additional properties of an innovation capability: persistence over time and complementarity (Tavassoli and Karlsson, 2015; Camison and Villar-Lopez, 2014; Doran, 2012; Mothe and Nguyen, 2010). It, therefore, refines the original definition of OI by Damanpour and Evan (1984), and supplements the definition of the OECD (2005), by considering OI not only as an innovation performance but also as an innovation capability that represents all the changes oriented to improve the core processes in an organization.

Second, it contributes to the OI generation literature from the resource-based perspective. Extant research primarily focuses on either environmental factors or organisational factors to explain the generation of OI. Findings from previous research have certainly shed important lights on the determinants of OI. Yet, there are still gaps in our understanding of the generation of OI. Research from the resource-based perspective has vindicated the importance of capabilities in utilising resources to achieve superior firm performance. Framing OI as an innovation capability from the resource-based perspective, our study supplements previous research with a focus on environmental or organisational factors to advance understanding of the resource-led generation of OI. Although the effect of external and internal resources on technological innovations has been analysed in empirical research (Barney, 1991; Galende and de la Fuente, 2003; Anzola-Román et al., 2018), insufficient attention has been paid to resources 
as the drivers of organisational innovations (Damanpour et al., 2009; Martin-Rios and Pasamar, 2018). Thus, our research provides empirical evidence on the effect of resources on the generation of OI, confirming the similarity in the drivers of technological innovation and OI. Moreover, extant research seldom considers the dual role of internal and external sources of generation of OI. Damanpour et al.'s (2018) research redress this by investigating the dual role of internal and external sources of knowledge and information on the adoption of managerial innovation. We extend their important work by considering and confirming the dual role of internal and external resources in the generation of OI. Our findings corroborate the dual importance of open innovation and in-house capability development. The results also pose a new research question concerning the relative importance between internal and external resources in response to the deglobalisation in the current business environment. Furthermore, we extend the knowledge of the generation of OI by showing the cumulative effect of OI over time. This result indicates that OI shows a similar property of persistence over time as technological innovation (Peters, 2009; Sapprasert and Clausen, 2012). It is coherent with Amburgey and Miner (1992), Malerba and Orsenigo (1999), Triguero and Córcoles (2013), Tavassoli and Karlsson (2015), and Martin-Rios and Parga (2016), which highlight the effectiveness of reorganizing repeatedly.

Third, our research contributes to the literature of combinative effects of innovation types by providing fresh empirical evidence on the complementarity between OI and technological innovation. Recent reports have shown a direct relationship between these two types of innovation (Battisti and Stoneman, 2010; Damanpour, 2010; Mothe and Nguyen, 2010; Geldes et al., 2017), suggesting a reciprocal and complementary relationship among technological, product and process, innovations and OI. Our research confirms the existence of complementarity between OI and technological innovation. This is in line with the works of Camison and Villar-Lopez (2014), Geldes et al. (2017), Doran (2012), Gunday et al. (2011), and Mothe and Nguyen (2010). Furthermore, our findings indicate that the interrelationship between OI and technological innovation is simultaneous rather than sequential. The finding that the simultaneous interrelation between OI and technological innovation indicates a greater affinity between process innovation and OI than between product innovation and OI. It is in line with the works of Damanpour (2010), Mothe and Nguyen (2010), and Camison and VillarLopez (2014). The complementary nature of the relationship between OI and technological innovation suggests that when two types of innovation are undertaken concurrently, there is a greater willingness to carry out the third type of innovation, than when each type of innovation is carried out separately. This is line with the findings of Hullova et al. (2016), that report a 
reciprocal relation between technological innovations and OI, defined as a "synchronous adoption" of product, process and organisational innovation, and that rule out other types of relations like sequentiality or amensalism. In practice, the results are reflected in the process of new product development, which requires sharing routines, tasks and teams so that synergies are generated. This is best illustrated by the beer company Guinness, where the development of a new container for beer brought along changes in processes as well as in the organisation, both in job positions and in the firms' procedures (Trott, 2010).

Fourth, our research explores the effect of OI on firm performance, expanding the current analysis of the effect of firms' process and product innovation on firm performance. We confirm findings in extant research such as Armbruster et al. (2008), Gunday et al. (2011), Camison and Villar-Lopez (2014), Karsson and Tavassoli (2016), Geldes et al. (2017), Lee et al. (2017) and Anzola-Román et al. (2018), who note that OI has a positive effect on firm performance. This result is very important from the strategic point of view because this implies that OI allows the firm to obtain a competitive advantage (Anzola-Román et al., 2018; Camison and Villar-Lopez, 2014; Gunday et al., 2011). Nonetheless, our finding on the combinative effects of $\mathrm{OI}$ and technological innovation on firm performance indicates that there is no combinative effect, or synergistic effect, of both innovation types when they are concurrently undertaken. The positive and complementary effect occurs when the undertaking of technological innovation precedes OI. This finding is consistent with Camison and VillarLopez (2014), Doran (2012) and Mothe and Nguyen (2010) but different from Tavassoli and Karlsson (2016) and Damanpour et al. (2018). For example, Tavassoli and Karlsson (2016) find that those firms that choose to undertake more than one type of innovation are better off in terms of their future productivity. Damanpour et al. (2018) find that organisations that adopt the same composition of innovation types consistently over time are not better off and that organisations will perform well only if they diverge from the industry norm in adopting innovation types. Following McEvily and Chakravarthy (2002), our results may suggest that synergies between OI and technological innovations may have a time lag before its impact on FP becomes noticeable. This seems to imply that for OI to thrive, firms need to foster technological innovation first. However, we do not find evidence of sequentiality in the undertaking of OI and technological innovation, indicating that more research is needed to unpack the complementarity-performance nexus.

Our study of the integrated model of OI has opened up opportunities for future research. It is well established in the innovation literature that innovations can differ considerably in their novelty and radicalness and that radical innovation is different from incremental innovation in 
terms of attributes, sources and effects (Utterback, 1994). In OI literature, studies have touched upon organisational antecedents, relationships with other types of innovation, and combinative effects of their joint adoption on performance outcome. As far as the combinations of innovation types are concerned, they tend to investigate the composition of innovation types, including product innovation, process innovation, organisational innovation, marketing innovation, and managerial innovation. For example, Damanpour et al. (2009) examine the combinative effects of three innovation types (service innovation, technological process innovation, and administrative process innovation). Tavassoli and Karlsson (2016) analyse the effect of simple versus complex innovation strategies on firm performance. Rarely has the degree of innovation radicalness been incorporated into such studies. Nonetheless, innovation radicalness matters. An introduction of radical organisational routines, processes and methods may need to draw more from internal resources in a less resource munificent environment, suggesting varying effects of internal and external resources on the generation of OI. Also, radical organisational innovation may become too disruptive when the firm's innovation strategy prioritises incremental changes and efficiency. Likewise, radical technological innovation may not be effective if organisational changes are not aligned closely with its need (Azar and Ciabuschi, 2017). Such mismatch between types of innovation in terms of radicalness will certainly compromise the effectiveness of innovation strategy, thereby affecting firm performance. Thus, future research can probe innovation radicalness in the model along this direction. Relatedly, framing OI as innovation capabilities in our integrated model also opens up new opportunities to investigate how firms reconfigure innovation capabilities in response to external changes and internal strategic shift. The nature of the persistence of innovation in general and OI, in particular, indicates the cumulative effect of innovation. The innovation literature also reveals that innovation due to its degree of radicalness can be competenceenhancing in the case of incremental innovation and competence-destroying in the case of radical innovation (Tushman and Anderson, 1986). Moreover, competence-enhancing may also lead to competence rigidities (Leonard-Barton, 1992). All this suggests a more complicated picture of changes in capabilities and effects of capabilities on firm performance. Our integrated model of OI proposes and confirms a positive mediating role of OI as innovation capabilities in the relationship between resources and performance. The mediation role may become more complex if innovation radicalness and persistence are taken into consideration. Future research may probe these questions in this direction.

From the managerial point of view, the paper highlights the importance of introducing strategies and plans that promote OI. An adequate managerial policy oriented towards the 
increase in OI at the firm will have a positive impact on firm performance. The paper highlights the importance of investing in employees training, on an R\&D department or on the acquisition of external equipment and knowledge because that will favour the generation of OI, and ultimately improve firm performance. On a similar way, from a policy perspective, policymakers can enhance firms' innovation by introducing policies aimed at encouraging the generation or acquisition of the above mentioned internal and external resources.

In conclusion, we advance a more nuanced understanding of OI with regard to its generation, persistence, complementarity, and combinative effects on firm performance. We draw from the resource-based perspective and dynamic capabilities of the firm to develop and test an integrated model of OI that frames OI as an innovation capability to explore how OI is generated, interacts with other types of innovation, and impacts on firm performance. The results mostly support our argument. 


\section{References}

Anzola-Román, P., Bayona-Sáez, C., \& García-Marco, T. (2018). Organizational innovation, internal $\mathrm{R} \& \mathrm{D}$ and externally sourced innovation practices: Effects on technological innovation outcomes. Journal of Business Research, 91, 233-247.

Armbruster, H., Bikfalvi, A., Kinkel, S., \& Lay, G. (2008). Organizational innovation: The challenge of measuring non-technical innovation in large-scale surveys. Technovation, 28, 644-657.

Azar, G., \& Ciabuschi, F. (2017). Organizational innovation, technological innovation, and export performance: The effects of innovation radicalness and extensiveness. International Business Review, 26(2), 324-336.

Ballot, G., Fakhfakh, F., Galia, F., \& Salter, A. (2015). The fateful triangle: Complementarities in performance between product, process and organizational innovation in France and the UK. Research Policy, 44(1), 217-232.

Barney, J. (1991). Firm resources and sustained competitive advantage. Journal of Management, 17(1), 99-120.

Barney, J., Wright, M., \& Ketchen, J., Jr. (2001). The resource-based view of the firm: Ten years after 1991. Journal of Management, 27, 625-641.

Battisti, G., \& Stoneman, P. (2010). How innovative are UK firms? Evidence from the fourth UK community innovation survey on synergies between technological and organizational innovations. British Journal of Management, 21, 187-206.

Birkinshaw, J., \& Mol, M. (2006). How management innovation happens. MIT Sloan Review, 47(4), 81-88.

Birkinshaw, J., Hamel, G., \& Mol, M. J. (2008). Management innovation. Academy of Management Review, 33(4), 825.

Brandyberry, A. A. (2003). Determinants of adoption for organisational innovations approaching saturation. European Journal of Innovation Management, 6(3), 150-158.

Camisón, C., \& Villar-López, A. (2010). An examination of the relationship between manufacturing flexibility and firm performance: The mediating role of innovation. International Journal of Operations and Production Management, 30(8).

Camisón, C., \& Villar-López, A. (2014). Organizational innovation as an enabler of technological innovation capabilities and firm performance. Journal of Business Research, 67(1), 2891-2902. 
Camisón, C., Boronat, M., \& Villar, A. (2010). Technological strategic alliances and performance: The mediating effect of knowledge-based competencies. Journal of Strategic Management Education, 6(1), 1-22.

Černe, M., Kaše, R., \& Škerlavaj, M. (2016). Non-technological innovation research: evaluating the intellectual structure and prospects of an emerging field. Scandinavian Journal of Management, 32(2), 69-85.

Cohen, W. M., \& Levinthal, D. A. (1990). Absorptive capacity: A new perspective on learning and innovation. Administrative Science Quarterly, 35(1), 128-152.

Coombs, J. E., \& Bierly, P. E. (2006). Measuring technological capability and performance. $R \& D$ Management, 36(4), 421-438.

Crossan, M. M., \& Apaydin, M. (2010). A multi-dimensional framework of organizational innovation: A systematic review of the literature. Journal of Management Studies, 47(6), 1154-1191.

Damanpour, F. (1991). Organizational innovation: A meta-analysis of effects of determinants and moderators. Academy of Management Journal, 34, 555-590.

Damanpour, F. (2010). An integration of research findings of effects of firm size and market competition on product and process innovations. British Journal of Management, 21(4), 996-1010.

Damanpour, F., \& Aravind, D. (2012). Managerial innovation: Conceptions, processes, and antecedents. Management and Organization Review, 8(2), 423-454.

Damanpour, F., \& Gopalakrishnan, S. (2001). The dynamics of the adoption of product and process innovations in organizations. Journal of Management Studies, 38(1), 45-65.

Damanpour, F., Sanchez-Henriquez, F., \& Chiu, H. H. (2018). Internal and external sources and the adoption of innovations in organizations. British Journal of Management, 29(4), 712-730.

Damanpour, F., \& Schneider, M. (2006). Phases of the adoption of innovation in organizations: Effects of environment, organization, and top managers. British Journal of Management, 17 , 215-236.

Damanpour, F., Walker, R. M., \& Avellaneda, C. N. (2009). Combinative effects of innovation types and organizational performance: A longitudinal study of service organizations. Journal of Management Studies, 46(4), 650-675.

Doran, J. (2012). Are differing forms of innovation complements or substitutes? European Journal of Innovation Management, 15(3), 351-371. 
Eisenhardt, K. M., \& Martin, J. A. (2000). Dynamic capabilities: What are they? Strategic Management Journal, 21(10-11), 1105-1121.

Evangelista, R., \& Vezzani, A. (2010). The economic impact of technological and organizational innovations. A firm-level analysis. Research Policy, 39(10), 1253-1263.

Fagerberg, J., \& Verspagen, B. (2009). Innovation studies-The emerging structure of a new scientific field. Research Policy, 38(2), 218-233.

Galende, J., \& de la Fuente, J. M. (2003). Internal factors determining a firm's innovative behavior. Research Policy, 32, 715-736.

Geldes, C., Felzensztein, C. \& Palacios, J. (2017). Technological and non-technological innovations, performance and propensity to innovate across industries. The case of an emerging economy. Industrial Marketing Management 69, 55-66.

Germain, R. (1996). The role of context and structure in radical and incremental logistics innovation adoption. Journal of Business Research, 35(2), 117-127.

Gilsing, V., Nooteboom, B., Vanhaverbeke, W., Duysters, G., \& van den Oord, A. (2008). Network embeddedness and the exploration of novel technologies: Technological distance, betweenness centrality and density. Research Policy, 37(10), 1717-1731.

Grant, R. M. (1996). Prospering in dynamically-competitive environments: Organizational capability as knowledge integration. Organization Science, 7(4), 375-387.

Green, D. M., and J. A. Swets. (1966). Signal Detection Theory and Psychophysics. New York: Wiley

Gunday, G., Ulusoy, G., Kilic, K. \& Alpkan, L. (2011). Effects of innovation types of firm performance. International Journal of Production Economics, 133 (2), 662-676.

Hamel, G. (2006). The why, what, and how of management innovation. Harvard Business Review, 84(2), 72.

Hamel, G. (2009). Management innovation. Leadership Excellence, 26(5), 5.

Heredia, J., Geldes, C., Kunc, M. and Flores, A. (2019). New approaches to the innovation process in emerging economies. The manufacturing sector case in Chile and Peru. Technovation 59, 33-55.

Hullova, D., Trott, P., \& Simms, C. D. (2016). Uncovering the reciprocal complementarity between product and process innovation. Research Policy, 45(5), 929-940.

Jiménez Jiménez, D., \& Sanz Valle, R. (2011). Innovation, organizational learning and performance. Journal of Business Research, 64, 408-417.

Karlsson, C., \& Tavassoli, S. (2016). Innovation strategies of firms: What strategies and why? The Journal of Technology Transfer, 41(6), 1483-1506. 
Lam, A. (2005). Organizational innovation. In: Fagerberg, J., Mowery, D.C., Nelson, R.R. (Eds.), The Oxford Handbook of Innovation. Oxford University Press, Oxford, pp. 115-147. Leonard-Barton, D. (1992). Core capabilities and core rigidities: A paradox in managing new product development. Strategic Management Journal, 13(S1), 111-125.

Martin-Rios, C. \& Parga, E. (2016a). Service response to economic decline: Management innovation as enabler of organizational renewal. Journal of Business Research, 69(8), 28902900.

Martin-Rios, C. \& Parga, E. (2016b). The early bird gets the worm, but the second mouse gets the cheese: Non-technological innovation in creative industries. Creativity and Innovation Management, 25 (1), 6-17.

Martin-Rios, C. \& Pasamar, S. (2018). Service innovation in times of economic crisis: The strategic adaptation activities of the top EU service firms. $R \& D$ Management, 48(2), 195209.

McEvily, S. K., \& Chakravarthy, B. (2002). The persistence of knowledge-based advantage: an empirical test for product performance and technological knowledge. Strategic Management Journal, 23(4), 285-305.

Milgrom, P., \& Roberts, J. (1990). The economics of modern manufacturing: Technology, strategy, and organization. American Economic Review, 80(3), 511-528.

Milgrom, P., \& Roberts, J. (1995). Complementarities and fit strategy, structure, and organizational change in manufacturing. Journal of Accounting and Economics, 19(2), 179208.

Mohnen, P., \& Röller, L. H. (2005). Complementarities in innovation policy. European Economic Review, 49(6), 1431-1450.

Mol, M. J., \& Birkinshaw, J. (2009). The sources of management innovation: When firms introduce new management practices. Journal of Business Research, 62, 1269-1280.

Mothe, C. \& Nguyen, T. (2010). The link between non-technological innovations and technological innovation. European Journal of Innovation Management, 13, 313-332.

Mothe, C. \& Nguyen, T. (2012). Non-technological and technological innovations: Do services differ from manufacturing? An empirical analysis of Luxembourg firms. International Journal of Technology Management 57(4), 227-244.

Lee, R., Lee, J. H., \& Garrett, T. C. (2017). Synergy effects of innovation on firm performance. Journal of Business Research, 99, 507-515. 
OECD (2005). The measurement of scientific and technological activities Oslo Manual. Guidelines for collecting and interpreting innovation data (3rd ed.). Paris: OECD EUROSTAT.

OECD (2011). ISIC rev. 3 Technology Intensity Definition. OEDC Directorate for Science, Technology and Industry. https://www.oecd.org/sti/ind/48350231.pdf

Oeij, P. R., van der Torre, W., Vaas, F., \& Dhondt, S. (2019). Understanding social innovation as an innovation process: Applying the innovation journey model. Journal of Business Research, 101, 243-254.

Peteraf, M. A. (1993). The cornerstones of competitive advantage: A resource-based view. Strategic Management Journal, 14, 179-191.

Peters, B. (2009). Persistence of innovation: stylised facts and panel data evidence. The Journal of Technology Transfer, 34(2), 226-243.

Pino, C., Felzensztein, Ch., Zwerg-Villegas, A. M. \& Arias-Bolzmann, L. (2016). Nontechnological innovations: Market performance of exporting firms in South America. Journal of Business Research, 69, 4385-4393.

PITEC (2016). Panel de Innovación Tecnológica. Fundación Española para la Ciencia y la Tecnología. https://icono.fecyt.es/PITEC/Paginas/por_que.aspx

Polder, M., Leeuwen, G. V., Mohnen, P., \& Raymond, W. (2010). Product, process and organizational innovation: drivers, complementarity and productivity effects. $U N U-M E R I T$ Working Paper Series 2010-035.

Prajogo, D. I., \& Sohal, A. S. (2006). The integration of TQM and technology/R\&D management in determining quality and innovation performance. Omega, 34, 296-312.

Robbins, P., \& O'Gorman, C. (2015). Innovating the innovation process: an organisational experiment in global pharma pursuing radical innovation. $R \& D$ Management, 45(1), 76-93.

Sapprasert, K., \& Clausen, T. H. (2012). Organizational innovation and its effects. Industrial and Corporate Change, 21(5), 1283-1305.

Schmiedeberg, C. (2008). Complementarities of innovation activities: An empirical analysis of the German manufacturing sector. Research Policy, 37(9), 1492-1503.

Schmidt, T., \& Rammer, C. (2007). Non-technological and technological innovation: strange bedfellows? ZEW-Centre for European Economic Research Discussion Paper, (07-052).

Sharapova, D., \& Kattuman, P. (2010). Complementarities in the adoption of modern management practices and firm performance. Micro-Dyn Working Paper, (01/10).

Staropoli, C. (1998). Cooperation in R\&D in the pharmaceutical industry-the network as an organizational innovation governing technological innovation. Technovation, 18(1), 13-23. 
Tavassoli, S., \& Karlsson, C. (2015). Persistence of various types of innovation analyzed and explained. Research Policy, 44(10), 1887-1901.

Tavassoli, S., \& Karlsson, C. (2016). Innovation strategies and firm performance: Simple or complex strategies? Economics of Innovation and New Technology, 25(7), 631-650.

Triguero, A., \& Córcoles, D. (2013). Understanding innovation: An analysis of persistence for Spanish manufacturing firms. Research Policy, 42(2), 340-352.

Trott, P. (2010). Innovation Management and New Product Development, 5th ed.Pearson Education Limited, Harlow.

Tsai, K. H. (2004). The impact of technological capability on firm performance in Taiwan's electronics industry. Journal of High Technology Management Research, 15, 183-195.

Tushman, M. L., \& Anderson, P. (1986). Technological discontinuities and organizational environments. Administrative Science Quarterly, 31(3),439-465.

Urgal, B., Quintás, M. Á., \& Tomé, R. A. (2011). Conocimiento tecnológico, capacidad de innovación y desempeño innovador: el rol moderador del ambiente interno de la empresa. Cuadernos de Economía y Dirección de la Empresa, 14(1), 53-66.

Utterback, J. (1994). Mastering the Dynamics of Innovation. MA: Harvard Business School Press.

Volberda, H. W., Van Den Bosch, F. A., \& Heij, C. V. (2013). Management innovation: Management as fertile ground for innovation. European Management Review, 10(1), 1-15. 
Table 1. Descriptive analysis

\begin{tabular}{|c|c|c|c|c|c|c|c|c|c|c|c|c|c|c|}
\hline & \multicolumn{2}{|l|}{ OI1 } & \multicolumn{2}{|c|}{ OI2 } & \multicolumn{2}{|c|}{ OI3 } & \multicolumn{8}{|c|}{ OI Total } \\
\hline & $\mathrm{N}$ & $\%$ & $\mathrm{~N}$ & $\%$ & $\mathrm{~N}$ & $\%$ & 0 & $\%$ & 1 & $\%$ & 2 & $\%$ & 3 & $\%$ \\
\hline \multicolumn{15}{|l|}{ Size: } \\
\hline - 11-49 & 534 & 27.4 & 522 & 26.8 & 192 & 9.9 & 1287 & 66.1 & 229 & 11.8 & 271 & 13.9 & 159 & 8.2 \\
\hline - $\quad 50-249$ & 645 & 40.1 & 605 & 37.6 & 217 & 13.5 & 863 & 53.6 & 207 & 12.9 & 360 & 22.4 & 180 & 11.2 \\
\hline$\bullet \quad>250$ & 402 & 57.2 & 367 & 52.2 & 170 & 24.2 & 267 & 38 & 86 & 12.2 & 197 & 28 & 153 & 21.8 \\
\hline Local Market & 1575 & 33.7 & 1501 & 32.1 & 580 & 12.4 & 2819 & 60.3 & 544 & 11.6 & 830 & 17.7 & 484 & 10.3 \\
\hline National Market & 1594 & 34.7 & 1527 & 33.3 & 596 & 13 & 2711 & 59 & 543 & 11.8 & 840 & 18.3 & 498 & 10.8 \\
\hline UE Market & 1447 & 37 & 1382 & 35.4 & 539 & 13.8 & 2209 & 56.5 & 482 & 12.3 & 768 & 19.6 & 450 & 11.5 \\
\hline \multicolumn{15}{|l|}{ Finance: } \\
\hline - Local & 335 & 51.7 & 298 & 46 & 134 & 20.7 & 269 & 41.4 & 103 & 15.9 & 164 & 25.3 & 112 & 17.3 \\
\hline - National & 464 & 53.9 & 442 & 51.3 & 221 & 25.7 & 338 & 39.3 & 113 & 13.1 & 216 & 25.1 & 194 & 22.5 \\
\hline - $\quad \mathbf{U E}$ & 101 & 63.9 & 90 & 57 & 49 & 31 & 46 & 29.1 & 25 & 15.8 & 46 & 29.1 & 41 & 25.9 \\
\hline Cooperation & 705 & 55 & 657 & 51.2 & 311 & 24.3 & 482 & 37.6 & 192 & 15 & 343 & 26.8 & 265 & 20.7 \\
\hline External R\&D & 602 & 53.1 & 568 & 50.1 & 264 & 23.3 & 440 & 38.8 & 177 & 15.6 & 294 & 25.9 & 223 & 19.7 \\
\hline External equipment & 355 & 57.6 & 317 & 51.5 & 136 & 22.1 & 222 & 36 & 97 & 15.7 & 180 & 29.2 & 117 & 19 \\
\hline Knowledge external & 38 & 62.3 & 38 & 62.3 & 18 & 29.5 & 19 & 31.1 & 7 & 11.5 & 18 & 29.5 & 17 & 27.9 \\
\hline Training & 336 & 63.6 & 312 & 59.1 & 152 & 28.8 & 147 & 27.8 & 93 & 17.6 & 157 & 29.7 & 131 & 24.8 \\
\hline \multicolumn{15}{|l|}{ Innovation Product: } \\
\hline$\bullet \quad$ Good & 1016 & 50.3 & 967 & 47.8 & 411 & 20.3 & 850 & 42.1 & 297 & 14.7 & 525 & 26 & 349 & 17.3 \\
\hline - Services & 343 & 65.7 & 326 & 62.5 & 177 & 33.9 & 143 & 27.4 & 73 & 14 & 145 & 27.8 & 161 & 30.8 \\
\hline \multicolumn{15}{|l|}{ Innovation process: } \\
\hline - Manufacturing & 962 & 56.4 & 894 & 52.4 & 387 & 22.7 & 618 & 36.2 & 267 & 15.7 & 484 & 28.4 & 336 & 19.7 \\
\hline - Logistic & 390 & 76.3 & 358 & 70.1 & 189 & 37 & 96 & 18.8 & 68 & 13.3 & 172 & 33.7 & 175 & 34.2 \\
\hline - Support & 676 & 70.7 & 598 & 62.6 & 288 & 30.1 & 225 & 23.5 & 153 & 16 & 325 & 34 & 253 & 26.5 \\
\hline
\end{tabular}


Table 2. Duality property: Internal and external resources as drivers of OI

\begin{tabular}{|c|c|c|c|c|}
\hline VARIABLES & $\begin{array}{l}1) \\
\text { OII }\end{array}$ & $\begin{array}{l}2) \\
\text { OI2 }\end{array}$ & $\begin{array}{l}3) \\
\text { OI3 }\end{array}$ & $\begin{array}{l}4) \\
O I \\
\end{array}$ \\
\hline R\&D Staff & $\begin{array}{l}0.76 \text { *** } \\
(0.20)\end{array}$ & $\begin{array}{l}0.51 * * * \\
(0.19)\end{array}$ & $\begin{array}{l}0.67 * * * \\
(0.22)\end{array}$ & $\begin{array}{l}0.61 * * * \\
(0.19)\end{array}$ \\
\hline Training & $\begin{array}{l}0.55^{* * * *} \\
(0.09)\end{array}$ & $\begin{array}{l}0.58 \text { *** } \\
(0.09)\end{array}$ & $\begin{array}{l}0.36^{* * *} \\
(0.11)\end{array}$ & $\begin{array}{l}0.66 * * * \\
(0.09)\end{array}$ \\
\hline Cooperation & $\begin{array}{l}0.47 * * * \\
(0.08)\end{array}$ & $\begin{array}{l}0.43 * * * \\
(0.08)\end{array}$ & $\begin{array}{l}0.73 * * * \\
(0.10)\end{array}$ & $\begin{array}{l}0.57 * * * \\
(0.08)\end{array}$ \\
\hline External R\&D & $\begin{array}{l}0.28 * * * \\
(0.08)\end{array}$ & $\begin{array}{l}0.27 * * * \\
(0.08)\end{array}$ & $\begin{array}{l}0.23 * * \\
(0.10)\end{array}$ & $\begin{array}{l}0.40 * * * \\
(0.08)\end{array}$ \\
\hline External equipment & $\begin{array}{l}0.47 * * * \\
(0.08)\end{array}$ & $\begin{array}{l}0.34 * * * \\
(0.07)\end{array}$ & $\begin{array}{l}0.23 * * \\
(0.09)\end{array}$ & $\begin{array}{l}0.47 * * * \\
(0.08)\end{array}$ \\
\hline External knowledge & $\begin{array}{l}-0.04 \\
(0.24)\end{array}$ & $\begin{array}{l}-0.24 \\
(0.23)\end{array}$ & $\begin{array}{l}0.01 \\
(0.26)\end{array}$ & $\begin{array}{l}-0.20 \\
(0.23)\end{array}$ \\
\hline Information source & $\begin{array}{l}5.17 * * * \\
(0.45)\end{array}$ & $\begin{array}{l}4.34 * * * \\
(0.43)\end{array}$ & $\begin{array}{l}5.30 * * * \\
(0.52)\end{array}$ & $\begin{array}{l}4.89 * * * \\
(0.43)\end{array}$ \\
\hline Public Funding & $\begin{array}{l}0.13^{*} \\
(0.08)\end{array}$ & $\begin{array}{l}0.05 \\
(0.07)\end{array}$ & $\begin{array}{l}0.28 * * * \\
(0.10)\end{array}$ & $\begin{array}{l}0.11 \\
(0.07)\end{array}$ \\
\hline OECD & $\begin{array}{l}0.15 \\
(0.11)\end{array}$ & $\begin{array}{l}0.24 * * \\
(0.11)\end{array}$ & $\begin{array}{l}0.11 \\
(0.13)\end{array}$ & $\begin{array}{l}0.14 \\
(0.10)\end{array}$ \\
\hline Log Size & $\begin{array}{l}0.57 * * * \\
(0.05)\end{array}$ & $\begin{array}{l}0.46 * * * \\
(0.05)\end{array}$ & $\begin{array}{l}0.48^{* * * *} \\
(0.06)\end{array}$ & $\begin{array}{l}0.49 * * * \\
(0.05)\end{array}$ \\
\hline Group & $\begin{array}{l}-0.07 \\
(0.11)\end{array}$ & $\begin{array}{l}0.10 \\
(0.11)\end{array}$ & $\begin{array}{l}-0.24^{*} \\
(0.14)\end{array}$ & $\begin{array}{l}-0.03 \\
(0.11)\end{array}$ \\
\hline International & $\begin{array}{l}0.14 \\
(0.14)\end{array}$ & $\begin{array}{l}0.15 \\
(0.13)\end{array}$ & $\begin{array}{l}0.03 \\
(0.17)\end{array}$ & $\begin{array}{l}0.18 \\
(0.13)\end{array}$ \\
\hline $\begin{array}{l}\text { Observations } \\
\text { Number of firms } \\
\text { Model chi-square }\end{array}$ & $\begin{array}{l}14,427 \\
3,280 \\
605\end{array}$ & $\begin{array}{l}14,427 \\
3,280 \\
489.3\end{array}$ & $\begin{array}{l}14,427 \\
3,280 \\
411.5\end{array}$ & $\begin{array}{l}14,427 \\
3,280 \\
651.3\end{array}$ \\
\hline
\end{tabular}

Standard errors in parentheses. $* * * \mathrm{p}<0.001, * * \mathrm{p}<0.01, * \mathrm{p}<0.05$ 
Table 3. Mediating property and complementarity: The effect of OI and technological innovation in FP

\begin{tabular}{|c|c|c|c|c|c|}
\hline VARIABLES & $\begin{array}{l}(1) \\
\log \text { FP }\end{array}$ & $\begin{array}{l}(2) \\
\text { Log FP }\end{array}$ & $\begin{array}{l}(3) \\
\text { Log FP }\end{array}$ & $\begin{array}{l}\text { (4) } \\
\text { Log FP }\end{array}$ & $\begin{array}{l}\text { (5) } \\
\text { Log FP }\end{array}$ \\
\hline A(no OI, L_OI) & $\begin{array}{l}0.05 * * * \\
(0.01)\end{array}$ & & & & \\
\hline $\mathrm{A}(\mathrm{OI}$, no L_OI $)$ & $\begin{array}{l}0.05 * * * \\
(0.01)\end{array}$ & & & & \\
\hline $\mathrm{A}\left(\mathrm{OI}, \mathrm{L}_{-} \mathrm{OI}\right)$ & $\begin{array}{l}0.07 * * * \\
(0.01)\end{array}$ & & & & \\
\hline Y(no OI, pci) & & $\begin{array}{l}-0.02 * * * \\
(0.01)\end{array}$ & & & \\
\hline $\mathrm{Y}(\mathrm{OI}$, no pci) & & $\begin{array}{l}0.01 \\
(0.01)\end{array}$ & & & \\
\hline $\mathrm{Y}(\mathrm{OI}, \mathrm{pci})$ & & $\begin{array}{l}-0.01 \\
(0.01)\end{array}$ & & & \\
\hline X(no OI, pdi) & & & $\begin{array}{l}-0.01 \\
(0.01)\end{array}$ & & \\
\hline $\mathrm{X}(\mathrm{OI}$, no pdi) & & & $\begin{array}{l}0.02 \\
(0.01)\end{array}$ & & \\
\hline $\mathrm{X}(\mathrm{OI}, \mathrm{pdi})$ & & & $\begin{array}{l}0.00 \\
(0.01)\end{array}$ & & \\
\hline B(no OI, L_pdi) & & & & $\begin{array}{l}0.05 * * * \\
(0.01)\end{array}$ & \\
\hline B(OI, no L_pdi) & & & & $\begin{array}{l}0.07 * * * \\
(0.01)\end{array}$ & \\
\hline B(OI, L_pdi) & & & & $\begin{array}{l}0.07 * * * \\
(0.01)\end{array}$ & \\
\hline $\mathrm{C}$ (no OI, L_pci) & & & & & $\begin{array}{l}0.06 * * * \\
(0.01)\end{array}$ \\
\hline $\mathrm{C}\left(\mathrm{OI}\right.$, no $\left.\mathrm{L} \_\mathrm{pci}\right)$ & & & & & $\begin{array}{l}0.06 * * * \\
(0.01)\end{array}$ \\
\hline C(OI, L_pci) & & & & & $\begin{array}{l}0.07 * * * \\
(0.01)\end{array}$ \\
\hline OECD & $\begin{array}{l}-0.03 * * \\
(0.02)\end{array}$ & $\begin{array}{l}-0.03 * \\
(0.02)\end{array}$ & $\begin{array}{l}-0.03 * \\
(0.02)\end{array}$ & $\begin{array}{l}-0.03 * * \\
(0.02)\end{array}$ & $\begin{array}{l}-0.03^{* *} \\
(0.02)\end{array}$ \\
\hline Log Size & $0.01 *$ & $0.01 *$ & $0.01 *$ & $0.01 * *$ & $0.01 *$ \\
\hline
\end{tabular}




\begin{tabular}{llllll}
\hline \multirow{3}{*}{ Group } & $(0.01)$ & $(0.01)$ & $(0.01)$ & $(0.01)$ & $(0.01)$ \\
& $0.13 * * *$ & $0.14 * * *$ & $0.14 * * *$ & $0.13 * * *$ & $0.13 * * *$ \\
International & $(0.01)$ & $(0.01)$ & $(0.01)$ & $(0.01)$ & $(0.01)$ \\
& $0.07 * * *$ & $0.07 * * *$ & $0.07 * * *$ & $0.06 * * *$ & $0.06 * * *$ \\
& $(0.01)$ & $(0.01)$ & $(0.01)$ & $(0.01)$ & $(0.01)$ \\
Observations & & & & & \\
Number of firms & 14,427 & 14,427 & 14,427 & 14,427 & 14,427 \\
Model chi-square & 3,280 & 3,280 & 3,280 & 3,280 & 3,280 \\
\hline
\end{tabular}

Notes: A( Organizational innovation, OI; Organizational innovation, L_OI)

$\mathrm{X}($ Organizational innovation, OI; product innovation, pdi)

Y(Organizational innovation, OI; process innovation, pci)

B(Organizational innovation, OI; product innovation, L_pdi)

$\mathrm{C}$ (Organizational innovation, OI; process innovation, L_pci)

L OI (organizational innovation developed in t-1, 2008-2010).

L_pci (product innovation developed in t-1, 2008-2010)

L_pdi (process innovation developed in $\mathrm{t}-1,2008-2010$ )

$* * * \mathrm{p}<0.001, * * \mathrm{p}<0.01, * \mathrm{p}<0.05$ 
Table 5. Interrelation and complementarity: The effect of the relation between technological and OI

\begin{tabular}{|c|c|c|c|c|c|}
\hline & (1) & (2) & & (1) & (2) \\
\hline VARIABLES & pci & pci & VARIABLES & pdi & pdi \\
\hline \multirow[t]{2}{*}{$\mathrm{X}(\mathrm{OI}$, no pdi) } & $0.59 * * *$ & $0.58 * * *$ & $\mathrm{Y}(\mathrm{OI}$, no pci) & 0.08 & 0.08 \\
\hline & $(0.12)$ & $(0.12)$ & & $(0.12)$ & $(0.12)$ \\
\hline \multirow[t]{2}{*}{ X(no OI, pdi) } & $-0.18 * *$ & $-0.14 *$ & Y(no OI, pci) & -0.13 & -0.09 \\
\hline & $(0.08)$ & $(0.08)$ & & $(0.08)$ & $(0.08)$ \\
\hline \multirow[t]{2}{*}{ X(OI, pdi) } & $1.15 * * *$ & $1.17 * * *$ & $\mathrm{Y}(\mathrm{OI}, \mathrm{pci})$ & $0.60 * * *$ & $0.61 * * *$ \\
\hline & $(0.10)$ & $(0.10)$ & & $(0.10)$ & $(0.10)$ \\
\hline \multirow[t]{2}{*}{ L_pci } & $3.64 * * *$ & $3.60 * * *$ & L_pdi & $3.75 * * *$ & $3.71 * * *$ \\
\hline & $(0.06)$ & $(0.06)$ & & $(0.06)$ & $(0.06)$ \\
\hline \multirow[t]{2}{*}{ L_OI } & $-0.19 * * *$ & $-0.21 * * *$ & L_OI & 0.03 & 0.01 \\
\hline & $(0.08)$ & $(0.08)$ & & $(0.08)$ & $(0.08)$ \\
\hline \multirow[t]{2}{*}{ OECD } & & $-0.21 * * *$ & OECD & & $0.30 * * *$ \\
\hline & & $(0.06)$ & & & $(0.06)$ \\
\hline \multirow[t]{2}{*}{ Log Size } & & $0.15 * * *$ & Log Size & & 0.04 \\
\hline & & $(0.03)$ & & & $(0.03)$ \\
\hline \multirow[t]{2}{*}{ Group } & & -0.03 & Group & & -0.03 \\
\hline & & $(0.07)$ & & & $(0.07)$ \\
\hline \multirow[t]{2}{*}{ International } & & -0.14 & International & & $0.40 * * *$ \\
\hline & & $(0.09)$ & & & $(0.09)$ \\
\hline Observations & 11,004 & 11,004 & Observations & 11,004 & 11,004 \\
\hline Number of firms & 3,207 & 3,207 & Number of firms & 3,207 & 3,207 \\
\hline Model chi-square & 3413 & 3395 & Model chi-square & 3596 & 3569 \\
\hline
\end{tabular}

Notes: X(Organizational innovation, OI; product innovation, pdi)

Y(Organizational innovation, OI; process innovation, pci)

L_OI (organizational innovation developed in t-1, 2008-2010).

L_pdi (process innovation developed in t-1, 2008-2010)

$* * * \mathrm{p}<0.001, * * \mathrm{p}<0.01, * \mathrm{p}<0.05$ 